\title{
Hip-Hop and Sport-An Introduction: Reflections on Culture, Language, and Identity
}

\author{
C. Keith Harrison \\ University of Central Florida University of Colorado at Colorado Springs
}

Life is suits. Baller makes them sport. ESPN_Life needs
sports. ( 2018 promotional advertisement by ESPN)

"I'm from west side, 60, s.t, I might got killed/Standin' so tall, they think I might got stilts/Legendary baller/like Mike/like Wilt."-Nipsey Hussle, Grinding All My Life (2018)

"Brothas always try to knock a brotha down/Knock me to my knees about a million times/Uncle said I'll never sell a million records/I sold a million records like a million times/These brothas shouldn't let me in/I ball so hard on ESPN/See my name come across on CNN/'Bout 6 minutes, you gonna see it again/'Bout 6 minutes, you gonna see me again."-Jay-Z, Crown (2013)

"I be in and out of arenas like I'm Scottie Pippen." Drake, Landed (2020)

\section{Proem}

In 2017, hip-hop music was the most prominent genre in the music industry according to Nielsen Media, accounting for $24.5 \%$ of all music consumed (Caulfield, 2018). This marked the first time hiphop had finished year-end No.1, overtaking the perennial category leader, rock music. As if to symbolically codify this achievement, 12-time Grammy-award winning rapper and songwriter Kendrick Lamar headlined the halftime show at the College Football Playoff National Championship game on January 8, 2018. And while this performance squarely located hip-hop artists and their music as centrally located within the mainstream of contemporary sport culture, the links between hip-hop and sport are decidedly not new. Numerous examples abound, from the groundbreaking Run-DMC/ Adidas partnership of the mid-1980s; to the prominence of Nike and Michael Jordan within hip-hop communities in the 1990s; to more recently with the Jordan Brand signing endorsement deals with hip-hop artists Drake, Travis Scott, and DJ Khaled; Serena Williams appearing in Beyonce's visual album, Lemonade; Jay-Z founding Roc Nation Sports athlete management company in partnership with high-profile Hollywood talent firm Creative Artists Agency (and representing stars such as Kevin Durant, Kyrie Irving, Saquon Barkley, and Skyler Diggins-Smith). In addition, and as the prelude to NBA playoff games, you will often hear J.

Harrison is with the College of Business Administration, University of Central Florida, Orlando, FL, USA. Coakley is with the University of Colorado at Colorado Springs, Fort Collins, CO, USA. Harrison (scholarballer51@yahoo.com) is corresponding author.
Cole, Kendrick Lamar, and others singing as Black male bodies and minds perform. This extends as well to the WNBA, where Skee-Lo's song "I Wish"-with its hook "I wish I was a baller"—is part of a recent WNBA promotional campaign, particularly important because being a "baller" in this visual text is inclusive rather than exclusive of gender. ${ }^{1,2}$

Put differently, hip-hop is a mainstream, commercialized, and ever-growing billion-dollar industry fawned over by global brands and consumed by a wide spectrum of audience demographics. Hiphop circulates in the air we all breathe. Its presence ranges from cheerleading competitions with an entire category dedicated to hiphop to numerous mainstream commercials featuring hip-hop music, dance, style, slang, and energy as the focused positioning of the brands and representations of the products being sold. Movies and television sitcoms have utilized and capitalized on hip-hop culture across drama, comedy, and animation projecting various hip-hop cultural themes and influencers, including DJ Khaled, Kanye West, Cardi B, and more. And it is not just localized in the United States; as Motley and Henderson (2008) remind us, "From New York, to Paris, Tokyo, Sydney and localities in between, hip-hop culture is a Diaspora spanning ethnic, linguistic, and geographic boundaries" (p. 243). This is also true of its connection to sport, where English football clubs are mainstays in the work of artists such as Black Josh and Lee Scott; where global sports apparel brand PUMA's 2017 ad campaign "Suede Gully" "integrated Indian graffiti, street dance, and Hip Hop in four languages to woo millennials" (Srivastav, 2017); and where Australian cricketer Usman Khawaja's "dab" celebration in a test match against Pakistan recently "ignited debate" over the on-field celebration (Ferris, 2017).

Beyond the cultural artifacts described previously, hip-hop has permeated the language of sport. Recall the late ESPN broadcaster, Stuart Scott, who kicked down the door with his tongue and took the viewer on "an intoxicating intellectual rollercoaster ride" (Farred, 2000, p. 100) with "an almost poetic turn of phrase" (p. 111). Scott reminded us that many of the Black bodies (and other colors, shapes, and sizes) whose performances we celebrate are closely tied with hip-hop's spoken word and poetry. As Farred (2000) wrote regarding Scott in his analysis of ESPN's SportsCenter nearly 20 years ago:

Especially when basketball players such as Shawn Kemp or Shaquille O'Neal throw down that earth-shattering dunk, Scott will say that they are "representin." Against the backdrop of spectacular highlight footage, the visual soul of SportsCenter, Scott will extend his hip-hop speak into an ambivalent commentary about how Shaq is "in your face.” Kemp's thunderous dunk functions as a narrative shorthand for the machismo of a 
"gangsta rap" video-these basketball players, in rap discourse, are "gettin it on" .... Scott knows that he is doing more than melding the discourses of sports talk and Hip Hop . .

. Scott, in an epistemological sense, is "representing" the Black basketball players, and the sociopolitical context that produces them. (p. 114)

Today, Hip Hop culture is squarely ensconced in mainstream language. Check out your local grocery store when you go to grab ice cream or other related frozen items as the sliding door for these products often say, "Chill out." The statement to "diss" somebody, "swagger," and "bling" are now regularly deployed in White, middle-class lexicons. It is fascinating to see the dominant borrowing (and sometimes the cultural theft) of the hip-hop tongue in mainstream popular culture. This also includes the cringeworthy moments, such as the Nathan's Hot Dog mascot rapping before the famous Coney Island eating contest or the Colonel Sanders Kentucky Fried Chicken logo personality doing the latest hip-hop gestures and dance moves (both of which border on-or even cross the line into-cultural appropriation used in the service of global capitalism). Hip-hop mogul and entrepreneur Damon Dash calls this the work of culture vultures (see Dash \& Griggs, 2017).

Hip-hop also contributes to representations and performances of identity, often in ways that cut against the stereotypical grain. In her 2019 book, On the Come Up, Angie Thomas tells an engaging story about a young woman immersed in hip-hop and committed to becoming a rapper. Based on Thomas's observations and experiences, this young woman saw herself in hip-hop as she grew up. She did not see herself - or people who really looked like her-in books, mainstream media, or films. Yet, rap represented her experiences and identity. Hip-hop spoke to her in a way that she could understand. Despite elements of misogyny, it expressed the voices of the people she knew, described the social world in which she lived, and provided her a framework for interrogating that world. Rap was so affirming that it inspired Thomas (2019) to write The Hate $U$ Give, a best-selling, award-winning novel that later was made into a feature film of the same name in 2018 starring Amandla Stenberg.

C. Keith Harrison (left), pictured with Jay Coakley (right) in Figure 1, felt similarly to Thomas (2019) in that he did not see student-athletes being rewarded for their pursuits in the classroom as often as they were being rewarded for their athletic pursuits. As a former student-athlete himself, Harrison has set out to change that narrative. So, in 1995, Harrison created the "Scholar-Baller"

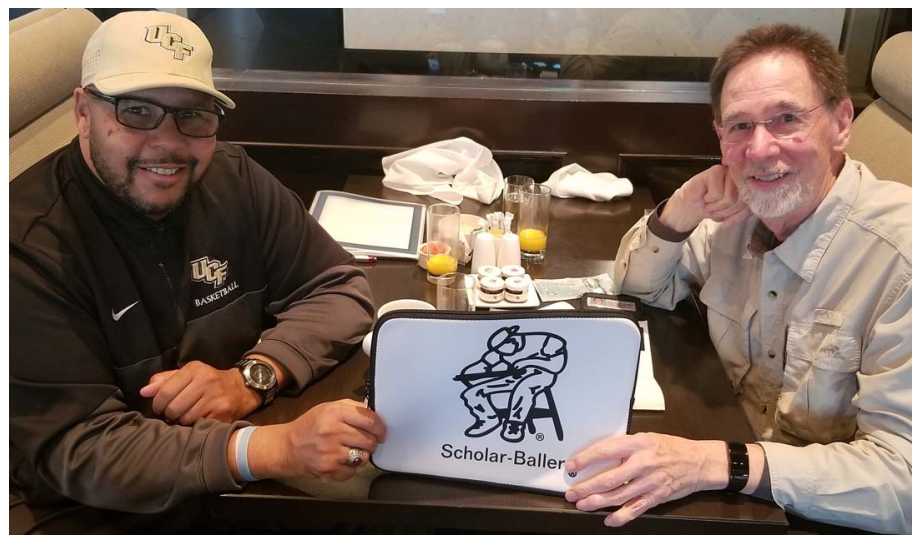

Figure 1 - C. Keith Harrison and Jay Coakley with the Thinkman image. concept (also co-founded a non-profit organization in 2005 that seeks to inspire youth and young adults to develop leadership skills and to excel in education in life by using their cultural interests in sport and entertainment [i.e. Hip-Hop]). One of the groundbreaking initiatives that the organization pioneered involves rewarding student-athletes that have earned a 3.0 grade point average or higher, with patches and/or stickers that can be adorned on their uniforms or helmets. These patches and stickers feature the Thinkman logo, that is being held by Harrison and Coakley in Figure 1, or the Thinkwoman logo that is featured in Figure 2.

The previous examples remind us of the power of art and culture in society, as theorists from Max Weber, Antonio Gramsci, and Theodor Adorno and the Frankfurt School, to Stuart Hall and the Birmingham School, cultural studies scholars such as bell hooks, and an array of structuralists and poststructuralists have long chronicled. Expressed in various ways, these keen observers of social life saw art in all its forms as a cultural practice linked closely with power relations in society. Although art often reaffirmed the status quo, it was also a medium through which oppressed populations could express resistance to the status quo with revolutionary zeal.

As diverse forms of hip-hop have permeated popular culture worldwide, rap lyrics have become the poetry of oppressed people, primarily people of color. They express feelings, thoughts, and actions in ways that we have not adequately studied in the social sciences, including the sociology of sport. This limits our knowledge of social reality because rap music and other forms of hip-hop mediate everyday experiences and relationships among millions of young people worldwide. In addition, rap beats and rapid-fire lyrics are now commonly used to heighten the excitement of sports events for millions of spectators and to calm, focus, and motivate athletes as they seek narratives representing their experiences and performances.

For these reasons, it was past time to consider the relationship between music and sports when Dr. Akilah Carter-Francique made it the theme of the 2018 conference of the North American Society for the Sociology of Sport (NASSS). The conference invited presentations on all forms of music-similar to the current issue of the Sociology of Sport Journal and how the articles focus on hip-

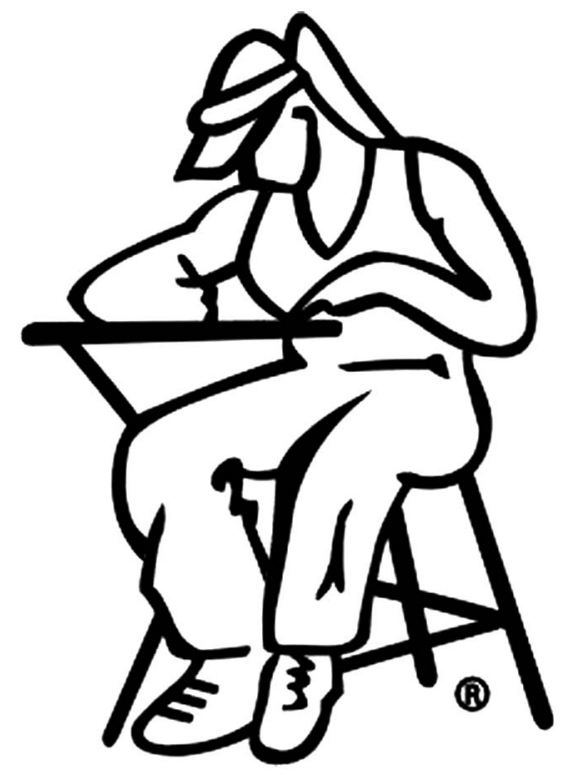

Figure 2 - Thinkwoman. 
hop, a music genre that has been integrated into sports at all levels and for many reasons. These contributions also legitimize and affirm the experiences and interests of our colleagues whose backgrounds and experiences differ from ours. Investigations of hip-hop probably will never fit neatly in particular disciplinary silos, but it is appropriate to include them in the sociology of sport.

As the voices of young people of color are being expressed more loudly and assertively than ever in literature, film, music, sports, and other cultural realms, it is past time to listen, learn, and pay them serious sociological attention. C.L.R. James (1993) insisted in American Civilization that it is in the serious study of popular culture above all "that you find the clearest ideological expression of the sentiments and deepest feelings of the American people and a great window into the future of America and the modern world" (p. 119). This issue of the Sociology of Sport Journal is an overdue step in treating seriously the popular intersection of hip-hop and sport, for Hip Hop culture, Hip Hop music, and Hip Hop generation athletes represent an important if inextricable thread in the fabric of contemporary sporting culture.

\section{Scholar-Baller ${ }^{\circledR}$ as Vernacular Intellectual (by C. Keith Harrison)}

I have lived the synergy of education, hip-hop culture(s), and sport with organic energy. In this section, and through a reflexive autobiographical account, I seek to highlight the evolution of hip-hop and sport over the last four decades. To this end, I write myself into and through this history as what Denzin (1997) would, after Sartre (1971/1981), frame as a universal singular. As Denzin writes (1997), "every life story is unique, yet representative of every other life story" (p. 47). Following Carrington (2008), my use of the autobiographical "is both strategic and partial, and used as much to reveal complexity and ambivalence as to produce analytical clarity and conceptual closure" (p. 426). Therefore, I situate the discussion of hip-hop and sport, and specifically, the scholarballer-that is, one who achieves and succeeds athletically and academically — as what Farred (2003) theorized as a vernacular intellectual. Setting the vernacular intellectual apart from Gramsci's notion of the organic intellectual, Farred explains:

The vernacular intellectual is distinguished from the Gramscian organic by a situatedness within the popular, frequently racialized experience of disempowered constituencies. While the organic is rooted in communities, the vernacular articulates an equivocal relationship to hegemony, a complex negotiation with the dominant group that is characterized by a self-conscious difference and defiance. The vernacular is defined by its immersion in the language of the popular, the particularities, idiosyncrasies, and distinctness of vernacular speech; the vernacular is marked by its ability to speak popular resistance and popular culture to power. (p. 12)

In my cultural view, a scholar-baller bridges intellectualism, entertainment, and sport with nuances external and internal to the intersection of culture, language, and identity. Farred again:

Their vernacularities share certain intellectual traits, such as preoccupation with the popular, but also speaks from different locales, to different publics that seldom overlap, and in different vernacular registers. What happens to the category of intellectual when it is interrupted, dislocated and vernacularized? How is the icon of popular culture transformed when he or she is represented as an intellectual or the vernacular or other variety? (p. 11)
In his work, Farred specifically highlights Muhammad Ali as a vernacular intellectual of the sporting tradition, noting that:

Ali spectacularized boxing as a cultural event both through the magnificence of his athletic skills and his introduction of an identifiably black speech into forums dominated by a white aesthetic of reserve, an arena where blacks were objects of rather than producers of commentary. Ali converted boxing's traditional venues from spaces that privileged the black body as mute spectacle into a platform for black physical and intellectual articulation. (p. 53)

It is in this regard that I present the following historical perspective of hip-hop and sport.

In 1979, my family moved from Gardena in southern California (near Compton and downtown Los Angeles) to Cerritos, a gateway city between Los Angeles county and Orange county, roughly 15 miles away. By that time, I had developed the routine of playing the song "Rapper's Delight" (1979) by The Sugarhill Gang while playing video game football on a Magnavox Odyssey game system with my peer Jeff Pecot every day-after we did our homework first. During those middle school and early high school days, I would often listen to my boombox late at night with various mixtapes, both underground and those with a slight tilt toward the mainstream, in the space of what was known as crossover in those days. Fast forward to 1984 when the movie Breakin' came out (after Wild Style in 1982), and Krush Groove after that in 1985 along-all of which featured hip-hop culture. Throughout 1984, house parties and backyard mixers with disk jockeys (DJs) and hiphop albums lugged around in crates were the status quo for our social life as Gen Xers growing up in a Reagan-era, post-Fast Times at Ridgemont High (1982) culture. In 1985, my freshmen year at Cerritos Community College, I wrote a rap for our football team that borrowed the theme song from the Fat Boys song "The Fat Boys are Back" to become "The Falcons are Back." The song was a celebration of the academic and athletic identities of our football team and, of course, our mutual passion for rap music and hip-hop culture. Little did I know that a simple locker room anthem would become the basis for my educational paradigm.

In 1986, my best friend Damon Andrews (a fellow studentathlete) and I dressed up in all black as Run-DMC at a party the Friday night before the big homecoming game against our rivals Fullerton College. (He was "Rev Run", i.e., Joseph Simmons; I was DMC, i.e., Darryl McDaniels, and rocked a St. John's starter jacket due to McDaniels attending the university in Queens, NY.) In 1988, flat tops, hip-hop, and sport began to intertwine more steadily. I vividly remember playing NWA, KRS-One, and "Top Billin" by MC Lyte as I flew Southwest Airlines to Amarillo, TX, on my recruiting trip to West Texas A\&M University. While a student-athlete there, the only time I got to hear hip-hop on mainstream radio in West Texas was Saturdays on one station for a very limited window.

Fast-forward to 1994 and the sociologist Tricia Rosewidely recognized as one of the first people ${ }^{2}$ in the United States to write her Ph.D. dissertation on hip-hop (at Brown University in 1993)_published Black Noise: Rap Music and Black Culture in Contemporary America. It was a genre-defining text that "examines the complex and contradictory relationships between forces of racial and sexual domination, black cultural priorities, and popular resistance in contemporary rap music" (p. xiii). Although Rose did not specifically engage with the question of sport vis-à-vis hip-hop, she discussed it much later during a 2010 talk in Boston: 
I was in high school at the time, and I paid no attention to [Hip Hop] particularly, but I listened to it. I was actually a basketball player; for a girl in that era, it was far more unusual than now. It was just Nancy Lieberman for those of you who know this, and she did not play with anybody because there were just a bunch of guys' pickup games. I mean there were no places for her to play pretty much. There was no WNBA. For younger people, that new place where girls play basketball didn't exist. So I was on the basketball courts a lot, which, that again was unusual, but that was really where Hip Hop was mostly practiced. If it was not a full-on block party itself, it was on the basketball court where the B-sides of disco records would be placed on one cassette, a dual cassette player. One would be the B-side and the other side would be whosever rap or rhyme that they have created, and they did it simultaneously.

I was enrolled in doctoral courses at the University of Southern California (USC) the same year Rose published Black Noise. It was there that I found myself in a counseling education course thinking through the scholar-baller dyad via a case study with the academic and athletic identities of Willie McGinest and Curtis Conway (USC football student-athletes on campus at that time) - the forerunner to a hip-hop curriculum I later put into practice as a faculty member at the Washington State University in 1996. It was also at this time that Matt Hicks conjured the Thinkman image that represented the first scholar-baller likeness for me that I had been brainstorming for years. Shout out to my first graduate student Algerian Hart for all his help during the Wazzu days.

In 1996, I also attended a keynote address given by Michael Eric Dyson to the National Black Graduate Student Conference in Claremont, CA: Dyson wore a three-piece suit ... and Jordan sneakers. In that moment, I witnessed a real-life scholar-baller as his keynote was educationally and intellectually dope and focused largely on culture, language, and identity. This was just a few years after his (1993) book Reflecting Black: African American Cultural Criticism helped to establish a particular genre of American cultural criticism. Importantly, the first chapter of that book was titled "The Culture of Hip Hop," and was positioned alongside other chapters that examined modern American Black popular and political culture, including Michael Jackson, Michael Jordan, Bill Cosby, Boyz $N$ the Hood, Malcolm X, and Toni Morrison, many others. Also, in 1996, Dyson delivered a winter graduation address at The University of North Carolina at Chapel Hill that was expressed as being "controversial" in the pages of the Daily Tar Heel in part because of Dyson's defense of rap music against its various critics (Dyson quoted from the lyrics of Snoop Dogg and the Notorious B.I.G.). Yet it is important to note that although there was (predictable) backlash, including a lukewarm apologia from the UNC Chancellor at the time to "concerned" parents, there was an equal if not more vigorous defense of Dyson (including in an editorial in The Daily Tar Heel, which closed by stating, "Dyson, instead of facing criticism, should have received a standing ovation" (see "Stand up for graduation speech," 1997). It is fitting, then, that Dyson contributed the Foreword to this special issue with a reflection on the life and importance of Tupac Shakur, framing him as "beautiful, contradictory, utterly self-destructive, edifying, hopeless, and hopeful-which is why he is the most complete symbol of a generation still evolving."

By 1997, I had joined the faculty at the University of Michigan. During my first semester, I used my last lecture to show a recap of the class with a slide projector presentation that captured the theme and title of the course "Race, Culture, and Sport." During the presentation, I played Puffy as he was known at that time and his song "Can't Nobody Hold Me Down." Some of the students bobbed their heads and sang the lyrics, letting me know that a connection was made. Yet I also had a student in a social/historical bases of sport class apologize that same day because he thought I was going to be a stereotypical and pigeonholed "Black male radical professor" all semester, and another apologize for questioning the use of Skee-Lo's "I Wish" for an assignment on the identity politics of race, gender, class, and culture. ${ }^{3}$ These events solidified for me the use of rap and hip-hop as a disrupter to heuristic thinking.

On April 9, 1998, we opened the Paul Robeson Research Center for Academic \& Athletic Prowess in Ann Arbor, MI. Dr. Richard Lapchick gave the keynote address and Aaron Celious, a doctoral student in sociology at the University of Michigan, performed a rap about the life of Robeson in the face of racism. Dr. Robert Sellers, a former (and still) scholar-baller during his linebacker days on Howard University's football team, gave remarks about the intersection of education, sport, and art in terms of Robeson's legacy. The scholar-baller synergy also included several standout student-athletes giving remarks (all alumni now), which included Dhani Jones (football) reading the 1919 valedictorian speech by Paul Robeson at Rutgers University, Traci Conrad (softball), Vanessa Lewis (soccer), Bobby Scales (baseball), and Jarrett Irons (my graduate student at the time). The success of this event laid in both the showcasing of education, Hip-Hop, and sport content as well as the intermingling of student-athletes and students from both of my spring courses.

The intersection of hip-hop and sport continued to evolve for me along with the world, including in the sociology of sport community. The progression of this overlap steered me to bring "The Notorious PhD," Todd Boyd, to deliver a keynote address at NASSS in 1999 in Cleveland, OH. The theme of that NASSS conference was "Sociology of sport at the millennium: Making a difference." Boyd's keynote, titled "The game is to be sold, not to be told: Race and sport in post-Clinton America," came on the heels of his then-recent book Out of Bounds: Sports, Media, and Identity (Baker \& Boyd, 1997), and foreshadowed his later work in Young, Black, Rich, and Famous: The rise of the NBA, the Hip Hop Invasion, and the transformation of American culture (Boyd, 2008). Boyd (2008) has often said of his role as a public intellectual:

My job is to make people think. I take this mandate very seriously. Thus my lectures, my writing, my movies, my commentaries, my very being all function to make people put their thinking caps on. Like Method Man, "I cam to bring the pain/hardcore to the brain." Therefore, I see myself as an agent provocateur, someone endowed with the responsibility of provoking thought. I find the best way to do that is not to say the same thing everyone else is saying but to say what needs to be said, to be real about what comes out of my mouth. In the academy I am a rarity, for so many say what they read in a book but have never lived. To me, you gotta live it, or else it is just rhetoric; don't talk about it, be about it. (pp. xvii-xviii)

Despite his illuminating keynote, I have to admit my most vivid memory of that particular conference is of Boyd and me trading rap verses from various hip-hop artists while sitting behind the Cavaliers bench with dope tickets and VIP access-all because Dr. Larry "Proc" Proctor (an exercise physiologist) had a conversation at a mixer with a successful older gentlemen who was impressed to see Black scholars (e.g., our crew) doing positive 
work in academe and society. Game recognized game as "Proc" came up on six of the best seats I have ever had at a NBA game.

And then, it seemed, things started to snowball. In 2001, an undergraduate at Michigan named Kyle Mason (after my request) drew the next iteration of the Thinkman image: a Thinkwoman illustration that immediately made Scholar-Baller more inclusive of gender and women's sports.

In 2002, Louisiana State University in Baton Rouge, LA, hosted a conference on "Race, Sport, and Hip Hop." Organized by Professors Louis Harrison, Jr. and Leonard Moore (both now at University of Texas-Austin), one could say this conference was a precursor to their annual Black Student Athlete Summit, which is an important intervention for many reasons. I went to the Georgia/ Louisiana State University football game during that conference with my pops; hip-hop music played during warm-ups and at halftime. Of course.

In 2003, Rush Philanthropic Arts Foundation-founded by visual artist Danny Simmons, media mogul Russell Simmons, and Joseph "Rev Run" Simmons of Run-DMC fame-and its Hip-Hop Summit Action Network (HSAN) hired its first Scholar-InResidence to work on projects from "Rock the Vote" to a conceptual model of artists and athletes' philanthropic influence on society in collaboration with New York University. The hip-hop community - and perhaps more importantly those funding research on the influence of hip-hop-explicitly started making connections to sport.

In 2004, HSAN hosted a panel at USC with many hip-hop artists (e.g., Snoop, Kanye); entrepreneurs (e.g., Damon Dash) scholars (e.g., Michael Eric Dyson); and athletes (e.g., Byron Chamberlain, Orlando Benjamin, and Marcellus Wiley). I also participated as one of the panelists. Held during the NBA All-Star weekend in Los Angeles, CA, this event coincided with HSAN and the Black Voter Rep Project registering more than 60,000 young voters ahead of the summit. On stage in USC's famed Bovard Auditorium, ${ }^{4}$ which in 1967 hosted a civil rights speech by Dr. Martin Luther King, Jr., HSAN cochair Damon Dash stated:

The hip-hop community is so powerful and, while some of us have been very successful entrepreneurs, it's just as important to acknowledge that we are a part of a larger community. We can make a difference by doing our part to empower kids to change the world. Voting is an important step toward that.

Herein lies the animating factor when considering the intersection of sport and hip-hop: it is one that, for all of its entertainment and consumerist positions, is inherently political. Which is why the imposition of, nee privileging of, hip-hop and its various cultural, linguistic, and identity formations, actors, and contributions to society within a higher education setting is so imperative. ${ }^{5}$

Over the next 15 years, the foregoing kinds of partnerships, conferences, and political struggles played out across the film and television screen (Get Rich or Die Tryin, Something from Nothing, and Dave Chappelle's Block Party); at the ballot box with the Presidential election of Barack Obama, as well as countless other successful Blacks (e.g., Cory Booker, Kamala Harris, Deval Patrick, Eric Holder, etc.) taking leading roles in national politics, and the activism represented by the likes of Colin Kaepernick (see Boykoff, 2018; Walton-Fisette, 2018; Chaplin \& Montez de Oca, 2019), LeBron James and his "I Promise School," and the Minnesota Lynx of the WNBA with their Black Lives Matter protest in 2017. And while all of them-to varying extents and degrees of impactillustrate the popular appeal and political force of hip-hop, I want to close this section by referencing a moment that may have been overlooked at the time, but illuminates the intersectional forces at work in this special issue. The setting is the 2019 College Football Playoff National Championship game held in Santa Clara, CA, which was won by Clemson University. As ESPN sportscaster Reece Davis interviewed Clemson University head football coach Dabo Swinney and other players during the trophy celebration, Christin Wilkins (\#42) and Clelin Ferrell (\#99) interjected with a scripted and unscripted narrative. Wilkins and Ferrell (2019) stated:

We got something to say. We on the west coast/we on the west coast/we on the west coast. A lot of y'all might understand this for any recruits out there if you want to come to a program where you got to worry about your coach all up in the locker room, dancing - come to Death Valley. ${ }^{6}$

What was likely lost on many viewers - though certainly not lost on their intended audience-was that Wilkins and Ferrell were mimicking and imitating the 1995 Source Awards insult of Bad Boy label owner P. Diddy Combs by Death Row's Suge Knight. (Both label producers were battling over artist recruits to sign with each of their respective labels.) As Knight commented at the time, "Any artists out there that want to stay a star and won't have to worry about the executive producer being all in the videos, all on the records, dancing - come to Death Row."

While many viewing this moment simply see two large Black men promoting their football team in a postgame interview, it is important that we humanize both Clemson student-athletes-true scholar-ballers no doubt-versus the stereotype of Black men propagated throughout popular culture (Gaston, 1986) and the commodification of Black male bodies (Smith \& Beal, 2007). Prior to the 2019 National Championship game, Mollie Ro Simon's (2018) article "14 Clemson football players celebrate December graduations" includes two Black males: Clelin Ferrell is featured as the two images and representations of educational success in the editorial about commencement. The first image shows Ferrell looking up in the crowd, probably with his eyes on his family as he holds his cap with this caption: "Clelin Ferrell, a Clemson football player, celebrates after getting his diploma during the graduation ceremony at Clemson University on Thursday, December 20, 2018." The second representation shows Ferrell with both his hands in the air much in the same way ballers celebrate touchdowns, sacks, or tackles. The caption reads, "Clelin Ferrell, a Clemson football player, celebrates during the graduation ceremony at Clemson University on Thursday, December 20, 2018." These images are culturally important because they project education, academics, intellectualism, completion, matriculation, and knowledge. Ferrell also graduated in 3.5 years.

In terms of his peer, Christin Wilkins not only graduated in 2.5 years, but he also completed his M.A. in athletic leadership by the December 2018 graduation. Furthermore, Wilkins on December 4, 2018, was named the winner of the 2018 William V. Campbell Trophy, which is presented to the top football scholarathlete in the nation-better known as the "Academic Heisman" award of college football. Wilkins also displayed on the back of his helmet a 3.0 sticker for every semester he had a B-grade (or higher) grade point average, which he did for eight terms in a row. Both of these players maximized their college experience in a predominantly White institution of higher education while at the same time created a moment in time that gave transparency to exactly what this special issue is ultimately about.

Although some may dismiss college football as a commercial endeavor in which the student in student-athlete is all too often 
marginalized or erased, consider the words of Robin D.G. Kelley (1997) when he writes:

in the struggles of urban youths for survival and pleasure inside capitalism, capitalism has become both their greatest friend and greatest foe. It has the capacity to create spaces for their entrepreneurial imaginations and their "symbolic work," to allow them to turn something of a profit, and to permit them to hone their skills and imagine getting paid. (p. 77)

As the circle comes full, it is not lost on me that Harvard University's Hutchins Center for African \& African American Research now sponsors the Nasir Jones Hip-Hop Fellowship, so named after the rap legend Nas. Funded by an anonymous donor who wanted Nas to be the face of the program, the Fellowship brings visiting scholars to be in-residence on campus and funds research and hip-hop related academic programs. At the announcement of the fellowship program in 2013, Nas stated, "Hip Hop is important like computer science. The world is changing. If you want to understand the youth, listen to the music. This is what's happening right under your nose." Previous holders of this fellowship include, among others, Bettina L. Love, Bikari Kitwana, Lakeyta Bonnette-Bailey, Pablo Herrera Veitia, Akua Naru, 9th Wonder (Patrick Denard Douthit), and John Jennings.

In fall 2020, I will join this accomplished group as a Nasir Jones Hip Hop Fellow. I feel like Andy Dufresne from the awardwinning film Shawshank Redemption (1994) after he carved his niche and broke out of jail with a rock hammer. It took a village for this hip-hop and sport thing to happen and in no way did I manifest any of it on my own. And if you will allow me this closing moment: I would like to give props to my pops/father, who passed away on December 31, 2018, and to my mother the strongest woman I know, for keeping it together through the storms of life. Daddy came a long way from telling me to "turn that noise down" when I was growing up to having full on discussions later in life about innovation, entrepreneurship, and the way hip-hop has evolved. And so, going from writing rap songs for the Cerritos Community College football team to talking about the intersection of hip-hop and sport at Harvard University some 35 years later? Well, my pops, as he would often say when something was accomplished coming from East Texas where he grew up (a rural area), "you're in hog heaven."

\section{The Articles}

With this special issue of the Sociology of Sport Journal, we sought contributions that would critically examine, debate, and shed light on the intersection of hip-hop culture and sport, in all of its manifestations, and especially as contemporary forms of entertainment and cultural expression that are closely linked with issues of race, gender, sexuality, social class, and age. ${ }^{7}$

In the first article ("Bad Boy for Life: Hip-Hop Music, Race, and Sports"), Earl Smith and Angela Hattery utilize P Diddy's "Bad Boys for Life" music video as a strategic point of departure in the quest for values and community in SportsWorld. In so doing, they pose an interruption to the "ideological" articulations of discourse on the relationship between hip-hop music and sports. They argue that, from the beginning of the entry of Black athletes into the White spaces of the so-called level playing sport field this integration upset the norms of both civility and history because for many in White America, the belief persists that these same athletes were not then and should not be today in those sacred spaces — or what Anderson (2015) terms "the white space" in his important article in Sociology of Race and Ethnicity. Through their empirical analysis of data on segregation and integration in SportsWorld, Smith and Hattery seek to demonstrate that things are not always as they seem.

In “'Where I'm From': Jay-Z's 'Hip Hop Cosmopolitanism,' Basketball, and the Neoliberal Politics of Urban Space" Thomas Oates examines the articulation of the "Black ghetto" to authenticity through the involvement of hip-hop star Jay- $Z$ in two highly publicized basketball-related ventures during 2003. During that year, Jay-Z organized a team for the Entertainer's Basketball Classic in Harlem's Rucker Park and joined a team of investors aiming to move the NBA's New Jersey Nets to a new arena in Brooklyn, NY. Utilizing a cultural studies approach, Oates explains the context through which basketball and hip-hop became articulated with authenticity, were deployed toward the goal of managing a career transition for Jay- $Z$ and was also used to gain public support for a controversial proposal to build an arena in the Atlantic Yards area of Brooklyn.

In "Jay-Z and O.J.: Sport and the Performance of Race in HipHop Music," Jamil Northcutt, Kayla Henderson, and Kaylee Chicoski examine the symbolic messaging in hip-hop music as it relates to the lived experiences and realities of Blacks in the United States. To this end, they deconstruct the song and music video titled, "The Story of O.J.," by Jay-Z. Of interest to them is unpacking the song's depiction of Blacks' lived experiences, in the United States, on their identity and ability to progress economically and socially regardless of social standing, within subcultures such as sport. Informed by critical race theory and using content analysis, Northcutt et al. identify three major themes for consideration: (a) battle with Blackness, (b) economic enslavement and financial freedom, and (c) systematic subjugation.

In "My Ambitionz az a Qualitative Ridah: A 2PAC Analysis of the Black Male Baller in Amerikkka," C. Keith Harrison, Rhema Fuller, Whitney Griffin, Scott Bukstein, Danielle McArdle, and Steven Barnhart contextualize and analyze the lyrics of Tupac Shakur as it relates to Black masculinity and the politics of racial performance. Utilizing critical race theory, the authors connect themes of the artists' (rapper) social commentary and the athlete (baller); specifically, those of: (a) trapped, (b) against the world, (c) Streetz R Death, and (d) Ambitionz. Synergy with the rapper and baller are articulated, as well as implications for scholars and practitioners that work with high school, collegiate, and professional Black male athletes, along with other men of color.

In “'Mike Trout When I'm Battin' Boy': Unpacking Baseball's Translation Through Rap Lyrics," Travis Bell and Victor Kidd deploy thematic analysis to explore how the languages of baseball and rap culture intersect through linguistic translation. The authors develop a broad understanding of positive and negative "baller" references and how it could affect future growth of baseball role models for Black youth athletes.

The special issue concludes with a series of provocative interviews by Reggie Saunders and C. Keith Harrison that are captured in an article titled "Rap sessions from the field: Intersectional conversations with Jemele Hill, Bun B, Fat Joe, and IDK," which reveals unique insights related to the themes of this special issue.

\section{Outro and Last Words: Conclusion and the Arc}

On May 22, 2020, the North American Society for Sport History held a virtual conference and I (Keith) posed the question, Where will sport history be 25 years from now? Twenty-five years (as 
opposed to five or 10) is forward-thinking enough to imagine radical change in sport having taken place in the interim-not only in terms of technological advances, advances for women athletes, global expansion, and myriad other issues we probably have not even dreamed to consider yet-but also to wonder how the historical analysis of hip-hop and sport will be told (as it barely finds mention in the sport history literature of the present day). Twenty-five years is also a specific temporal register in the context of this special issue, because 25 years ago (in 1995), Jay and I first met at NASSS in Sacramento, CA. Hip-hop, though thriving culturally in the preceding 15 years, had yet to make a dent in the sociology of sport literature, nor was it represented at the 1995 conference (even though theme of NASSS that year was "Cultural Diversity and the Sport Experience"). And so, it may have taken 25 years since that first meeting - and a lot of blood, sweat, and tears on the part of so many scholars, ballers, and activists-but we now have a special issue of the Sociology of Sport Journal that, hopefully, contributes both a lasting impression of what has come before but also serves as a spark to inspire the next generation of scholars writing on hip-hop and sport.

\section{Notes}

1. This gendered representation of the woman baller extends beyond sport: To give just one example, in the movie Ocean's 8 , Rihanna plays a woman from urban America with technological skills and introduces herself as "7 Ball" to the leader of the thief gang played by Sandra Bullock. Ms. Ocean's come back to Rihanna is, "You probably call yourself 8 Ball so I will call you 9 Ball." Rihanna responds, "Just call me Baller."

2. Another early intervention into this space was from the ethnomusicologist Cheryl L. Keyes, whose Ph.D. dissertation at Indiana University in 1991 was titled Rappin to the beat: Rap music as street culture among African Americans. She later published Rap Music and Street Consciousness (Keyes, 2004).

3. I told him if he could find a comparable song in country music or another genre that examined identity politics with race, gender, class, and culture that he could pick that song for the assignment. He could not find another song.

4. Twelve years prior, on my first day in my first doctoral course at USC, my professor, Dr. Penny Richardson, went over the syllabus then insisted that theory and practice be bridged. To demonstrate this point, we walked from the classroom in Waite Phillips Hall to Bovard Auditorium to witness the structured debate between Dinesh D'Souza and Nellie Strongman, who was on the faculty in USC's School of Education at the time. D'Souza was pushing the narratives that would animate his then-upcoming book The End of Racism (D'Souza, 1995), in which, among other things, he defended the Southern slave owner and put forth racist pseudoscience about intellectual inferiority among Blacks.

5. Although individual courses on hip-hop are taught at institutions of higher learning across the nation as well as globally, what about a concentration, a minor, or a certificate specific to hip-hop and sport? Prior to this special issue, hip-hop studies and sport sociology were binary in most academic outlets, lacking in-depth investigation of this relevant synergy. Yet Howard University taught the first class on hip-hop 30 years ago in 1991. In more recent years, the University of Arizona and Bowie State both introduced an undergraduate minor in hip-hop. North Carolina Central University now offers a concentration in hip-hop with their history degree. McNally Smith College of Music in St. Paul, MN offers a major and undergraduate diploma in hip-hop studies that focuses on hip-hop music as well as the marketing and economics of hip-hop culture. And Keith's institution, the University of Central Florida, at both the graduate and undergraduate level titled "The Business of Hip Hop Innovation and
Entrepreneurship," which to our knowledge are the first courses focused on and labeled with hip-hop in the course title to be taught in a College of Business in the United States and abroad (see Dudenhoefer, 2019).

6. As of this writing, video of this moment is still available on ESPN.com at https://www.espn.com/video/clip?id=25711042.

7. Despite our best attempts, we were unable to secure contributions from non-North American scholars

\section{Acknowledgments}

The authors thank all of the authors and reviewers for their contributions to this special issue, and send "big ups" to another SoCal person from where we both grew up, Professor Michael Giardina, for his endless support and attention to getting this special issue over the goal line and into the end zone!

\section{References}

Anderson, E. (2015). The White Space. Sociology of Race and Ethnicity, 1(1), 10-21. doi:10.1177/2332649214561306

Baker, A., \& Boyd, T. (1997). Out of Bounds: Sports, Media, and the Politics of Identity. Bloomington, IN: Indiana University Press.

Boyd, T. (2008). Young, Black, Rich, \& Famous: The rise of the NBA, the Hip Hop invasion and the transformation of American culture. Lincoln, NE: Bison Books.

Boykoff, J. (2018). Riding the lines: Academia, public intellectualism, and scholar-activism. Sociology of Sport Journal, 35(2), 81-88. doi:10. 1123/ssj.2018-0017

Carrington, B. (2008). What's the footballer doing here? Racialized performativity, reflexivity, and identity. Cultural Studies Critical Methodologies, 8(4), 423-452. doi:10.1177/1532708608321574

Caulfield, K. (2018, January 3). U.S. music consumption up $12.5 \%$ in 2017, R\&B/Hip Hop is year's most popular genre. Billboard. Retrieved from https://www.billboard.com/articles/columns/chartbeat/8085975/us-music-consumption-up-2017-rb-hip-hop-mostpopular-genre

Chaplin, K. S., \& Montez de Oca, J. (2019). Avoiding the issue: University students' responses to NFL Players' National Football League protests. Sociology of Sport Journal, 36(1), 12-21 doi:10.1123/ssj. 2018-0108

Dash, D., \& Griggs, K. (2017). Culture vultures. New York, NY: Poppington LLC.

Denzin, N. (1997). Interpretive ethnography. Thousand Oaks, CA: SAGE. Drake. (2020). Dark lane demo tapes [Album]. OVO Sound.

D'Souza, D. (1995). The end of racism. New York, NY: Free Press Paperbacks.

Dudenhoefer, N. (2019, August 15). An inside look at UCF's new hip-hop business classes. Retrieved from https://www.ucf.edu/news/aninside-look-at-ucfs-new-hip-hop-business-classes/

Farred, G. (2000). Cool as the other side of the pillow: How ESPN's SportsCenter has changed television sports talk. Journal of Sport \& Social Issues, 24(2), 96-117. doi:10.1177/019372350 0242002

Farred, G. (2003). What's my name? Black vernacular intellectuals. Minneapolis, MN: University of Minnesota Press.

Ferris, S. (2017, January 6). Khawaja's celebration ignites debate. Retrieved from https://www.cricket.com.au/news/usman-khawajadab-celebration-half-century-video-highlights-third-test-australia-scgpakistan/2017-01-06 
Gaston, J.C. (1986). The destruction of the young Black male: The impact of popular culture and organized sports. Journal of Black Studies, 16(4), 369-384. doi:10.1177/002193478601600402

Hussle, N. (2018). Victory lap [Album]. Atlantic Records.

James, C.L.R. (1993). American civilization. London, UK: Blackwell.

Jay-Z. (2013). Magna Carta holy grail [Album]. Jungle City Studios.

Keyes, C. (2004). Rap music and street consciousness. Urbana, IL: University of Illinois Press.

Kelley, R.D.G. (1997). Yo mama's dysfunctional: Fighting the cultural wars in urban America. Boston, MA: Beacon Press.

Motley, C. M., \& Henderson, G. R. (2008). The global hip-hop diaspora: Understanding the culture. Journal of Business Research, 61(3), 243-253. doi:10.1016/j.jbusres.2007.06.020

Sartre, J. (1981). Existentialism (C. Cosman, Trans.). Chicago, IL: University of Chicago Press. (Original work published 1971)

Simon, M. (2018, December 20). 14 Clemson football: 14 players receive degrees at December graduation. Independent Mail. Retrieved from. https://www.independentmail.com/story/news/2018/12/20/ clemson-football-christian-wilkins-clelin-ferrell/2363954002/

Smith, M.M., \& Beal, B. (2007). "So you can see how the other half lives": MTV "Cribs" use of "the Other" in framing successful athletics masculinities. Journal of Sport and Social Issue, 31(2), 103-127. doi: $10.1177 / 0193723507300483$

Srivastav, T. (2017, November 7). PUMA integrates Indian graffiti, street dance, and hip hop in four languages to woo millennials. Retrieved from https://www.thedrum.com/news/2017/11/07/puma-integratesindian-graffiti-street-dance-and-hip-hop-four-languages-woo

Stand Up for Graduation speech. (1997, January). Daily Tar Heel.

Thomas, A. (2019). On the come up. New York, NY: Harper Collins.

Walton-Fisette, T. (2018). Metaphorically taking a knee: Pausing, acting, reflecting. Sociology of Sport Journal, 35(4), 293-300.

Wilkins, C., \& Ferrell, C. (2019). Ferrell, Wilkins give rap-inspired recruiting pitch [video]. ESPN. Retrieved from https://www.espn. $\mathrm{com} / \mathrm{video} / \mathrm{clip}$ ?id=25711042 